\title{
Relationship between Fe-Cu-REEs mineralization and magnetic basement faults using multifractal modeling in Tarom region, NW Iran
}

\author{
${ }^{1}$ Department of Petroleum and Mining Engineering, South Tehran Branch, Islamic Azad University, Tehran, Iran; *Corresponding author, \\ E-mail: adib@azad.ac.ir \\ ${ }^{2}$ Geological and Environmental Research Center of Zemin Kav, Tehran, Iran \\ ${ }^{3}$ Department of Petroleum and Mining Engineering, South Tehran Branch, Islamic Azad University, Tehran, Iran
}

(Received: May 16, 2021; Revised accepted: July 12, 2021)

https://doi.org/10.18814/epiiugs/2021/021017

In this paper, a Concentration-Distance to Magnetic Faults (C-DMF) fractal model was applied to distinguish $\mathrm{Fe}, \mathrm{Cu}$ and REEs mineralized zones based on their distance to basement faults derived via airborne geophysical data and field survey maps in the Tarom region at the western Alborz-Azerbaijan belt, NW Iran. The application of the $C-D M F$ model was utilized for mineralization classification in the Tarom 1:100,000 sheet which reveals that the main $\mathrm{Fe}, \mathrm{Cu}$ and REEs mineralization have an inverse correlation with their distances to magnetic faults (fault lineaments). The $\mathrm{Cu}$ ores within acidic rocks and the $\mathrm{Fe} /$ REEs mineralization within intermediated rocks are located in the Northern and Southern parts of the Tarom region, respectively. Furthermore, the basement fault and intrusive rocks have overlapped and they have important roles for these metallic deposits/occurrences. Based on the CDMF log-log plots, $\mathrm{Fe}$, REEs and $\mathrm{Cu}$ high-grade mineralization values are larger than $48.31 \%$, and $3.8 \%$, with respective distances of 451 and $732 \mathrm{~m}$ to the nearest magnetic faults. The results obtained from the fractal modeling indicate a positive relationship between Fe, REEs mineralization and the basement faults. Consequently, Cu mineralization has a weak relationship to faults in comparison with $\mathrm{Fe}$ and REEs.

\section{Introduction}

Alborz-Azerbaijan zone is characterized by extensive Cenozoic magmatic activity with calc-alkaline-potassic character, in northwestern Iran (Berberian and King, 1981; Moinvaziri, 1985). The volcanic rocks of this zone have been formed in magmatic arc and back-arc tectonic setting in a post-collisional setting (Berberian, 1983; Allen et al., 2003; Hassanzadeh and Wernicke, 2016). The U-Th/He apatite isotopic data in the region is the Miocene continental collision of Iran
(Stockli et al., 2004). Iron-apatite ores host rare earth elements in the study region.

The recognition of the structural condition is significant for mineral exploration especially in reconnaissance and prospecting stages. Relationship between structures and mineralization is a fundamental study for regionalized exploration for magmatic and hydrothermal ore deposits (Pirajno, 2009; Mustansar et al., 2016). The ideas about the relationship between mineralization and geological structures were introduced in 1950s (Adib et al., 2017; Nabilou et al., 2018). Airborne geophysical data are useful instruments to determine structures especially basement faults (Safari et al., 2016; Ahmadfaraj et al., 2019). To explore the relationship between structures, several mathematical methods specifically fractal modeling are widely adopted (e.g., Agard et al., 2005; Safari et al., 2016; Adib et al., 2017; Nabilou et al., 2018; Ahmadfaraj et al., 2019). Distribution and dispersion of elements rely on geological features such as magmatic rocks, sedimentation, structures (e.g., faults), metamorphism and mineralization. These have self-similarity characteristics, so they can be explained by fractal/multifractal methodology (Mandelbrot, 1983; Turcotte, 1986; Meng and Zhao, 1991; Li et al., 2003; Agterberg, 2012; Daneshvar Saein et al., 2012; Afzal et al., 2014, 2015, 2017; Khalajmasoumi et al., 2016; Yasrebi and Hezarkhani, 2019; Kouhestani et al., 2019; Pourgholam et al., 2021). These studies have found a meaningful correlation between geological (e.g., geochemical, geophysical) and geometrical properties (Cheng et al., 1994; Hassanpour and Afzal, 2013; Karami and Afzal, 2015; Nazarpour, 2018). Nouri et al. (2013) developed fractal modelling according to the relationship between main/basement faults for mineral exploration in reconnaissance stage.

The current research aims to scrutinize the relationship between faults especially basement faults with $\mathrm{Fe}, \mathrm{Cu}$ and REEs mineralization in the 1: 100,000 Tarom sheet (NW Iran). These occurrences/deposits were classified based on their distance to NW basement faults (first generation of faults) by Concentration-Distance to Magnetic Faults (C-DMF) fractal model. In this research, faults are extracted from the airborne geophysical data and field observations. 


\section{Geological Setting}

The Alpine-Himalayan folded belt is divided into two branches including Alborz-Azerbaijan structural zone in the north and Zagros mountains at the south and southwest as a result of the closure of Tethys Ocean with the E-W trending in Iran Plateau (Davoudzadeh and Schmidt, 1984; Sengör, 1984). The western part of Alborz-Azerbaijan structural zone with WNW-ESE trending was distinguished by Cenozoic magmatic activities in Alpine-Himalayan folded belt (Berberian and King, 1981). This region was formed in tectonic conditions of magmatic and back arcs (Allen et al., 2003; Nabatian et al., 2014a; Tahmasbi et al., 2016; Wan et al., 2018).

There is magnetite-apatite mineralization which was originated from quartzmonzonite magma in relationship with the closure of NeoTethys Ocean (Fig. 1) and also Tarom batholith (Nabatian et al., 2014a,
2015; Mokhtari et al., 2018). Based on the geological map (Fig. 2), the deposits of Sorkheh-Dizaj, Ali Abad, Morvarid, Zaker, Golestan Abad deposits and their connection with some geological units and intrusive masses have been identified. The main intrusive masses at this area are composed of quartz monzonite to quartz monzodiorite and the coarse crystals with porphyritic texture including plagioclase, pyroxene and quartz. The minor minerals of these intrusive rocks are comprised of magnetite, zircon, apatite and sphene. Circulation of hydrothermal solutions or fluids into these intrusive masses have led to mineralogical changes including the conversion of plagioclase to clay minerals, sericite, epidote, and calcite.

The Tarom region (NW Iran) comprises of the metallic mines and deposits specially $\mathrm{Cu}, \mathrm{Fe}, \mathrm{Pb}, \mathrm{Zn}$, REEs with hydrothermal genesis (Mokhtari et al., 2018). These deposits (e.g., Morvarid and SorkheDizaj) are in metalorganic region with Late Eocene magmatic and volcano sedimentary host rocks (Nabatian et al., 2014). In Tarom region,

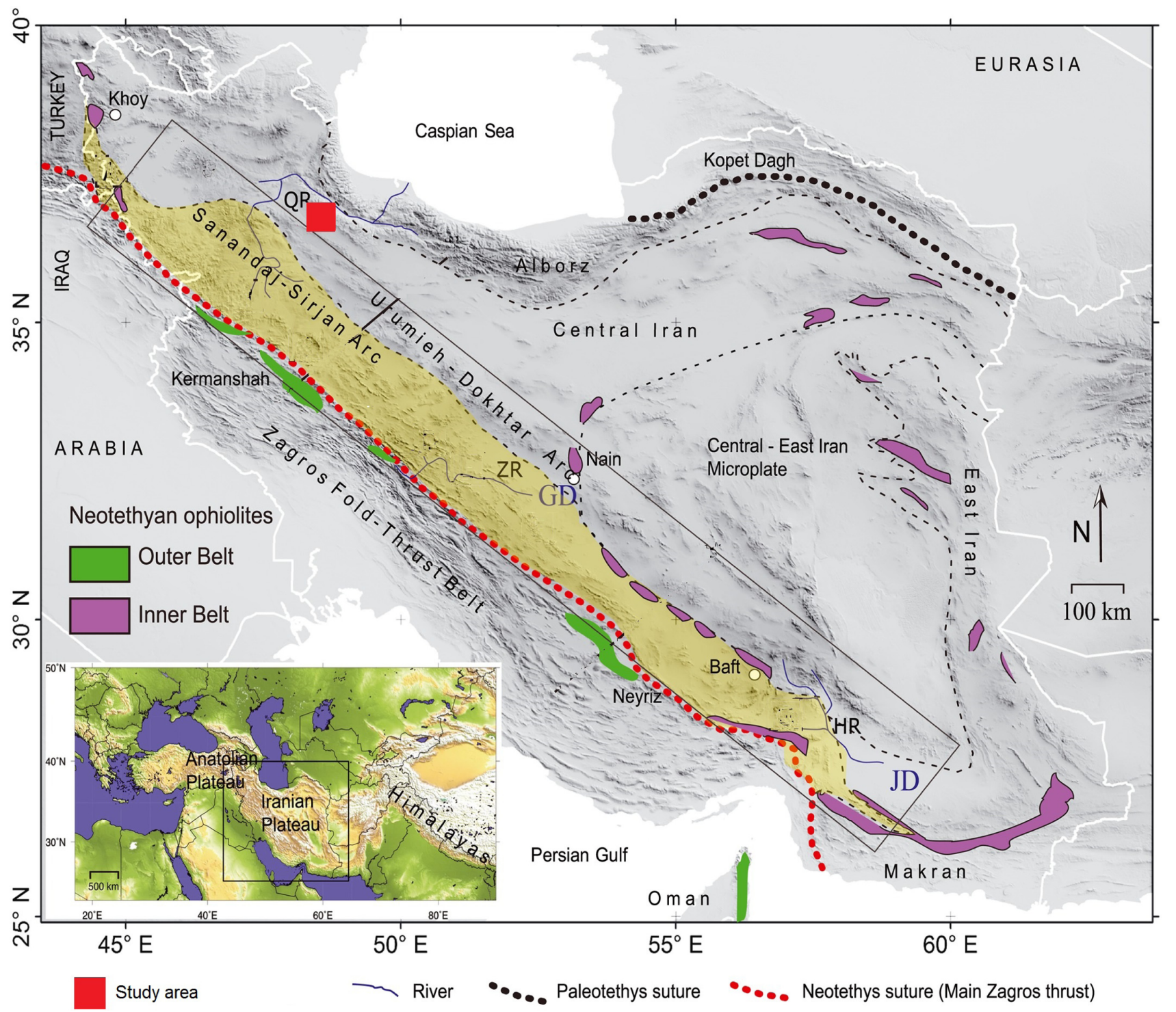

Figure 1. Sanandaj-Sirjan zone (yellow shading) within the broader Alpine-Himalayan collision zone (inset) and location of Paleotethyan and Neotethyan sutures (thick dashed lines), major boundaries of continental fragments (thin dashed lines), and ophiolite bodies (colored areas). Abbreviations: QR, Qezel Ozan Sefidrud River; ZR, Zayandehrud River; HR, Halilrud River; GD, Gavkhooni depression; and JD, Jazmurian depression (Hassanzadeh and Wernicke, 2016). 


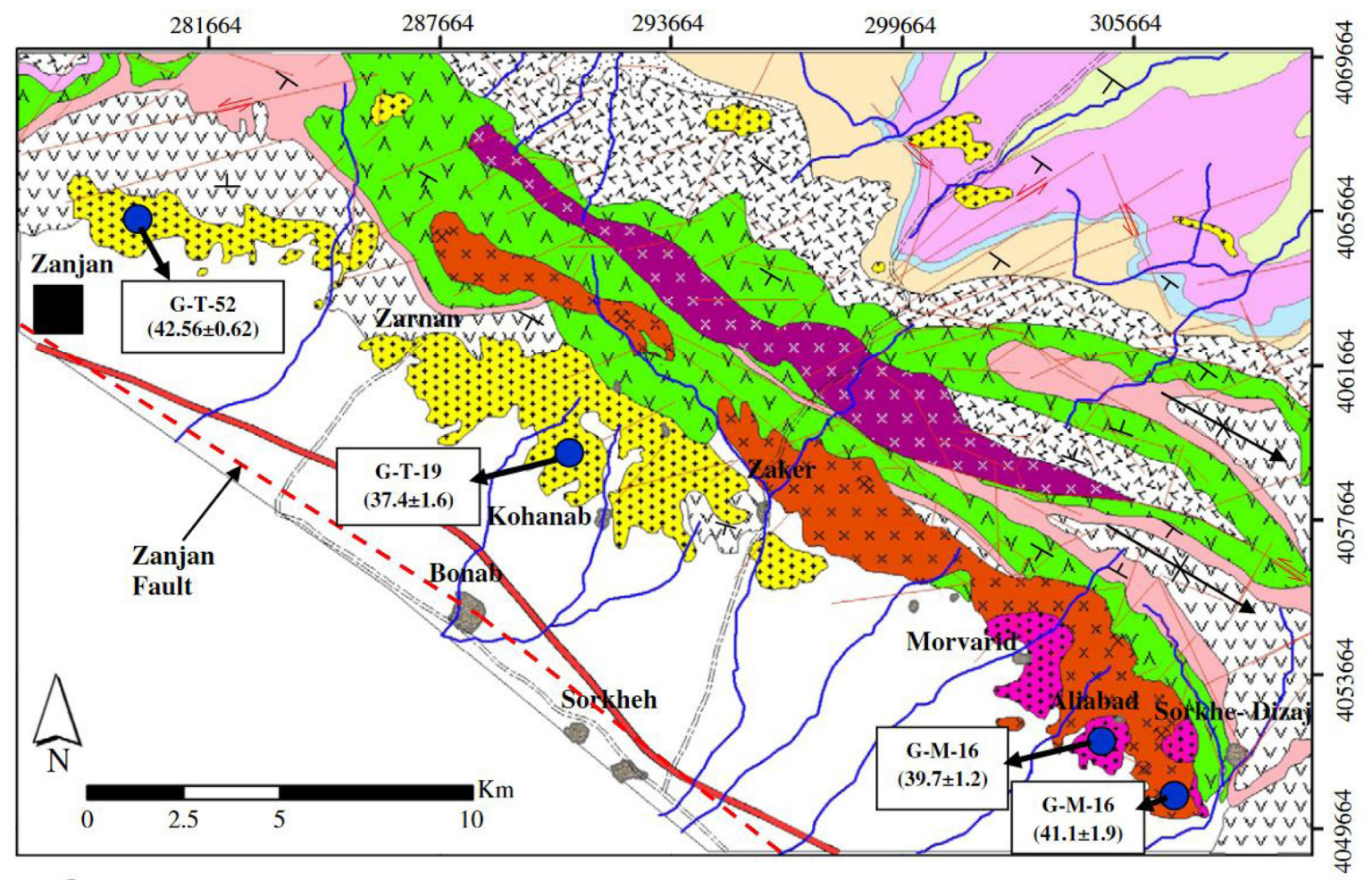

\section{Legend}

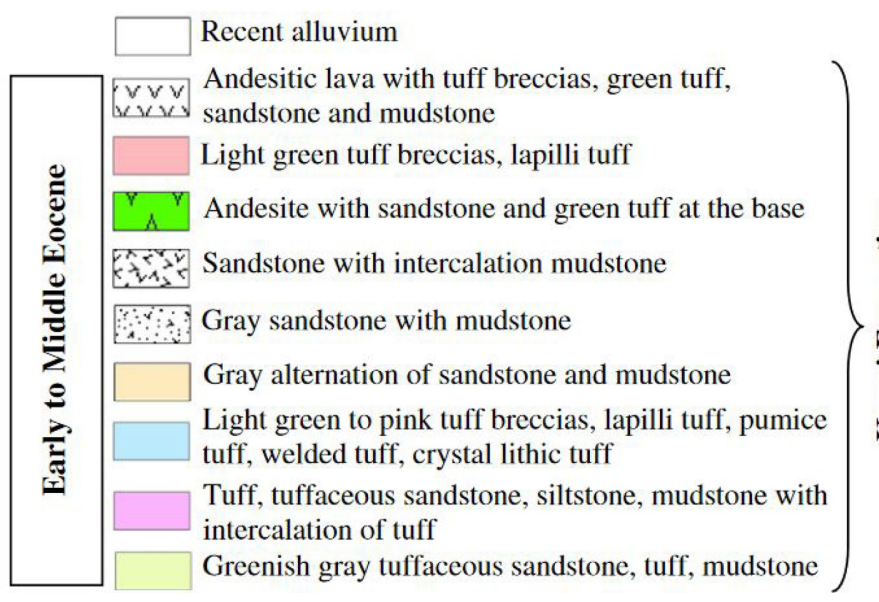

\section{Intrusive rocks}

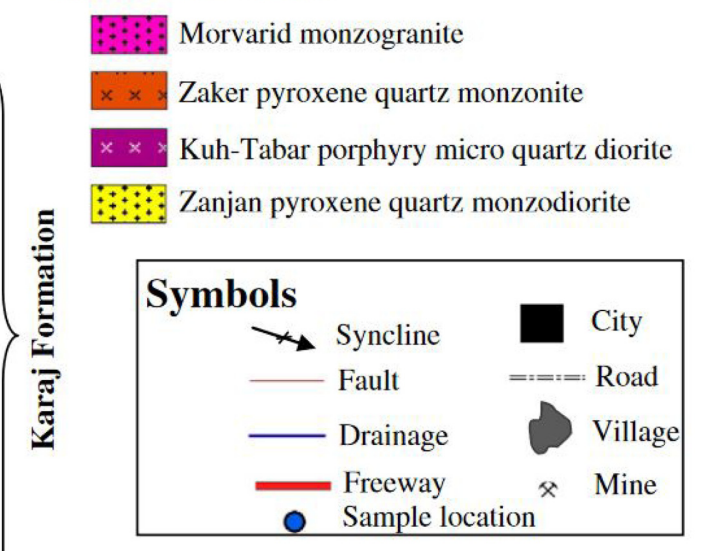

Figure 2. Geological map of the Tarom intrusive complex (Nabatian et al., 2014b).

$\mathrm{Fe}, \mathrm{Cu}$ and REEs mineralization has hydrothermal source such as the Fe-Cu-REEs deposits of the world (Nabatian et al., 2017).

Tarom area (Fig. 2) is located in the eastern Zanjan district, NW Iran. There are polymetallic deposits specifically $\mathrm{Fe}, \mathrm{Cu}$ and REEs (Nouri et al., 2013) which are part of the Tarom polymetallic zone as part of the Alpine-Himalayan Mountain Range. There are two great intrusive masses, volcanic rocks and other small outcrops with basic, acidic and intermediate compositions. Moreover, large granitic and granodioritic bodies intruded into the Eocene rocks. They represent intrusive bodies of the Pyrenean orogeny phase which intruded along the deep direction of NW-SE major fault zones in the Tarom mountain range (Fig. 2). There is sub-volcanic intrusions with silicisification, argillic, propylitic and sericitic alteration zones. The altered intrusions contain $\mathrm{Cu}, \mathrm{BP}, \mathrm{Zn}, \mathrm{Au}, \mathrm{Ag}$ and Fe ore minerals such as chalcopyrite, chalcocite, malachite, magnetite, galena and sphalerite. Mineralized
$\mathrm{Cu}$ veins including malachite, chalcocite, bornite and azurite occur in Eocene ignimbrites and tuffs which have similar trends to the major faults in the area, especially NNW-SSE (Azizi et al., 2010).

Mineralization of the iron oxide-apatite of the region mostly occurs in the form of veins within the intrusive mass of quartz monzonite to quartz monzodiorite, and to a lesser extent within the volcanic rocks of Eocene. Mineralization is detected in the NE-SW and E-W directions, and follows the faults extensions. In these deposits, mineralization embraces magnetite, apatite, monazite, and to a lesser extent pyrite, chalcopyrite and bornite, and still to a lesser extent mineral, e.g., ilmenite and spinel magnetite. There are many metallic mines/deposits such as Sorkh-Dizaj, Ali Abad, Morvarid, Zaker and their relationship are displayed in Fig. 2. The major intrusive rock is microquartz diorite/ monzonite as the main host rock of metallic ores especially in Morvarid deposit (Fig. 3; Nabatian and Ghaderi, 2014). 


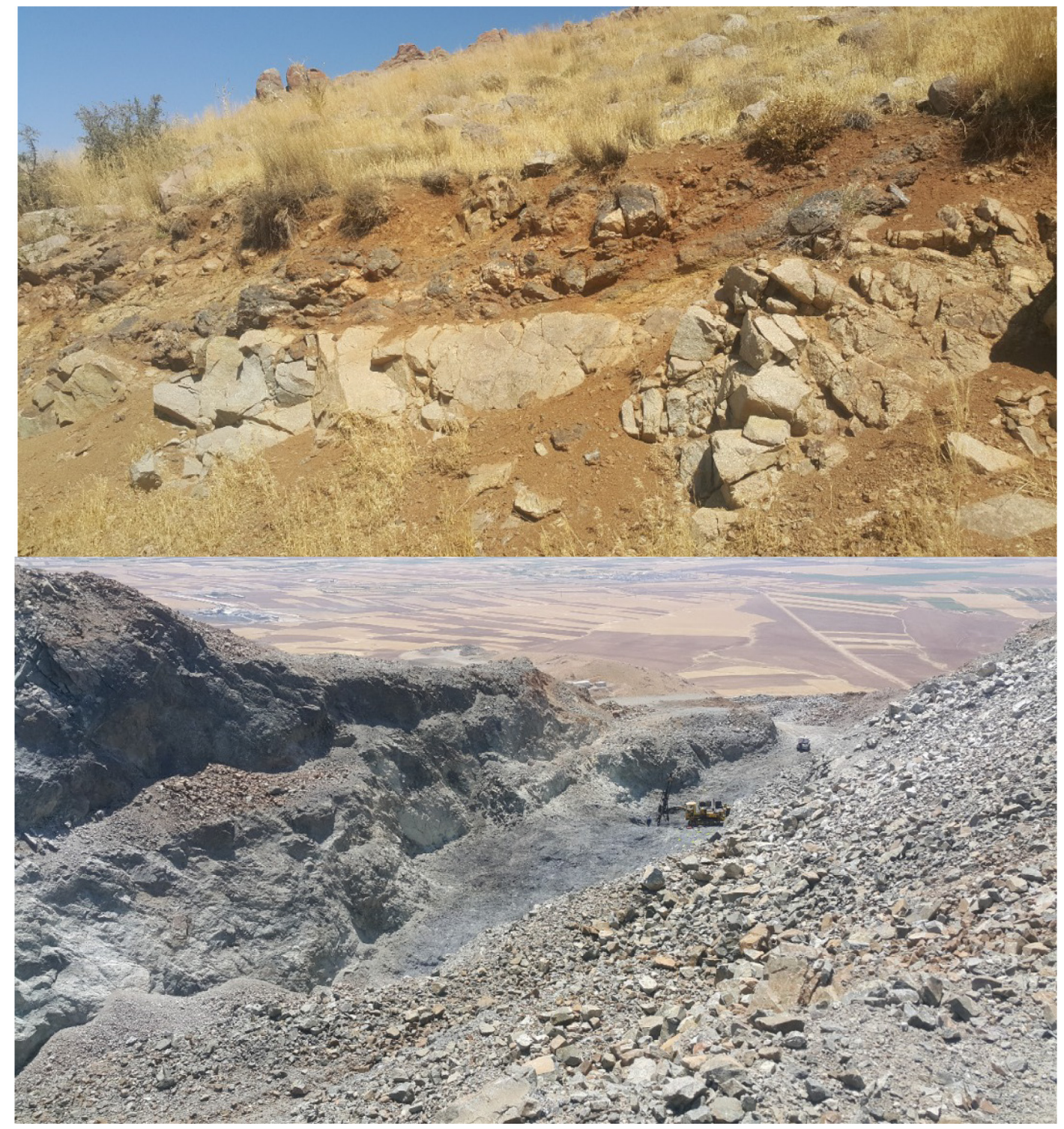

Figure 3. Mineralization of apatite iron ore within monzogranite to syenogranite and creation of economic reserve of iron and rare earth elements in Morvarid mine in Tarom belt of Zanjan.

In the study area, magnetite-apatite ores were formed as veins in intrusive rocks. The mineralogy of these deposits contains magnetite, apatite, monazite, actinolite, pyroxene, quartz, calcite and a little sulfidic mineralization such as pyrite, chalcopyrite and bornite. The trends of faults in the study area are NE-SW and NW-SE (Figs. 2 and 3). The mechanism of all of the faults related to the deposits (based on this research) are reverse/thrust (Nouri et al., 2013). Allen et al. (2003) and Guest et al. (2006) specified that the faults of western Alborz are sinistral strike slip such as Ipack, North Ghazvin and Roudbar faults (Fig. 4). On the other hand, most faults in the Zanjan region are dextral strike slip. Based on their intersections, there are several blocks in the form of wedges. Furthermore, there are short variations of crust's form due to the measurement of velocities (Vernant et al., 2004) and low values of seismic activities in Zanjan region (Tatar and Hatzfeld, 2009). The main faults in relationship with seismic, unconformities and mineralization activities are Soltanieh, Dizaj Abad and Morvarid faults (Solaymani et al., 2011).
The Soltanieh fault, as a strike slip fault, is more than $222 \mathrm{~km}$ between Abhar and Zanjan. The main feature form of this fault is the movement of Quaternary alluviums potentially responsible for the massive earthquake in 1803 (Berberian, 1983). The Morvarid fault is a strike slip fault of $20 \mathrm{~km}$ length and NNE-SW trending, and crosscut drainages to the left direction and other Quaternary features (Figs. 4 and 5).

\section{Materials and Method}

\section{Petrography and Ore Microscopy}

Field studies, petrography, ore microscopy, electron microprobe analysis (EMPA), ICP-MS, XRD and XRF are used to analyze the samples of the Tarom granitoides and mines. The analysis of minerals was performed by means of Philips-Xpert Pro XRD machine, and we 


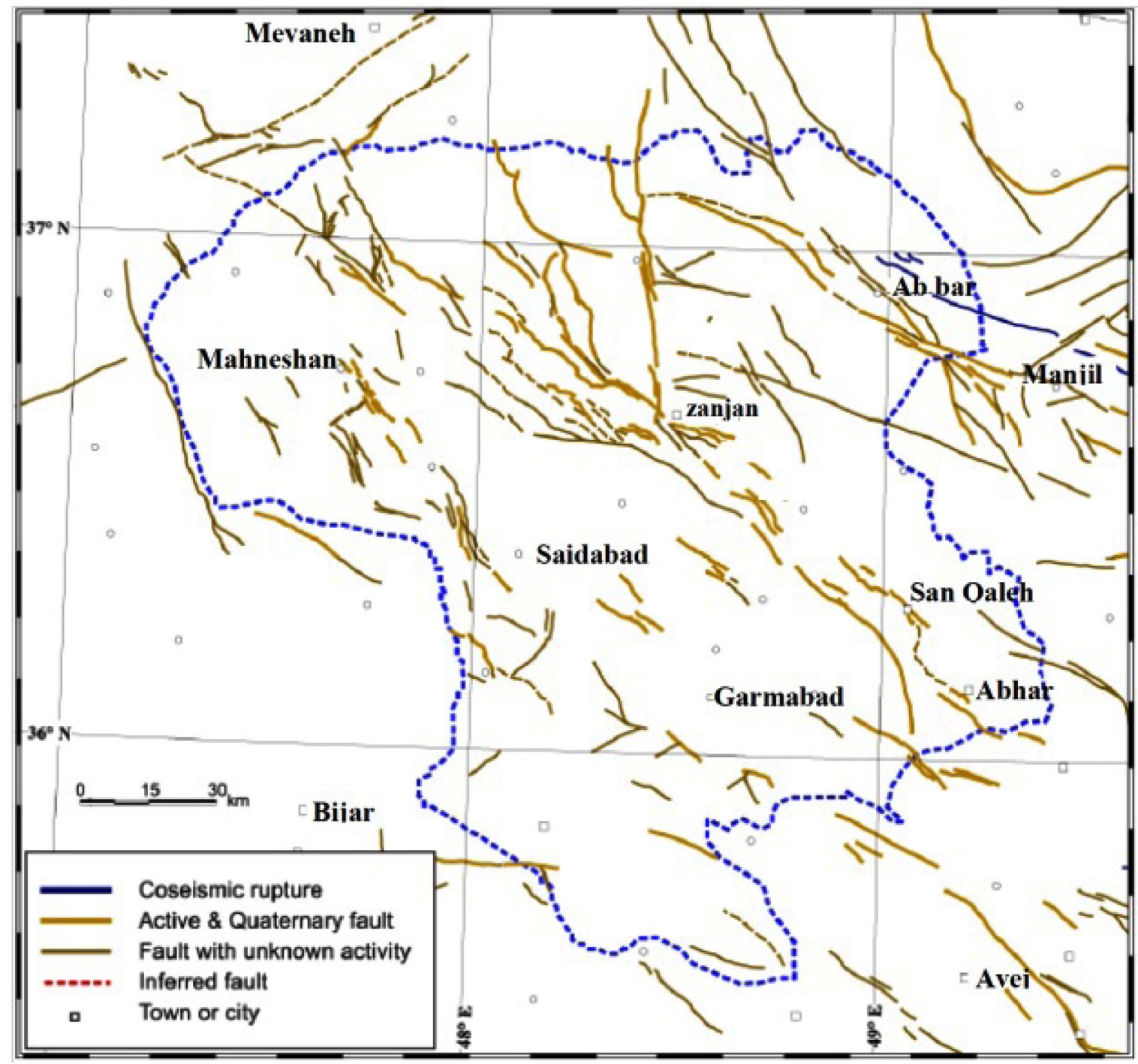

Figure 4. Active and Quaternary faults in the Zanjan Region (Solaymani et al., 2011).

have used Leo 1450 Vp Scanning Electron Microscope (SEM), and electron-probe microanalysis CAMECA EPMA (SX 100 model) to help identify minerals by their composition. Considering the mineralogy and ore microscopy studies, the most abundant minerals are magnetite (30-40\%), plagioclase (30-35\%), quartz and apatite (10-15\%), phlogopite (3-7\%), chlorite (2-4\%), zeolite (2-4\%), and calcite (about $2 \%$ ). hematite, goethite, and lepidocrocite are an iron-bearing oxide and hydroxide minerals. They are also formed with a frequency of $2-4 \%$ due to magnetite and pyrite modification: pyrite (about $2 \%$ ), covellite and sphalerite (less than 1\%). Monazite is also found in small amounts in the form of fluid inclusions in quartz and apatite (Fig. 6).

\section{Aeromagnetic Data and Reductions}

The key component of this study is the image enhancement of the existing aeromagnetic datasets acquired by the Geological Survey of Iran (GSI) in 2011. Aeromagnetic surveys were flown with a flight height of $150 \mathrm{~m}$ and a nominal flight line spacing of $500 \mathrm{~m}$ in direction NE-SW, perpendicular to the dominant trend of geology in the area. After applying the preliminary corrections of the measurements, the observed geomagnetic data was corrected using diurnal variations. To obtain magnetic anomalies associated with local magnetic variations of rocks, it is necessary to remove the normal geomagnetic field of the study area from the data. The normal geomagnetic field used for the reduction was the International Geomagnetic Reference Field (IGRF) computed by GEOMAG program.

\section{Magnetic Fault Extraction}

The airborne magneto metric data were practiced to delineate the subsurface structures of the Tarom area. This geophysical approach is the Analytic signal filter to demonstrate linear structures. This filter is incorporated with the "shaded relief image".

There are a number of approaches that involve working with quantities and calculations from the observed magnetic and gravity data. Additionally, they do not heavily rely on the magnetization direction. The best-known approach of this type is the analytic signal concept (Nabighian, 1972). Evidently, the vertical derivative of the magnetic 


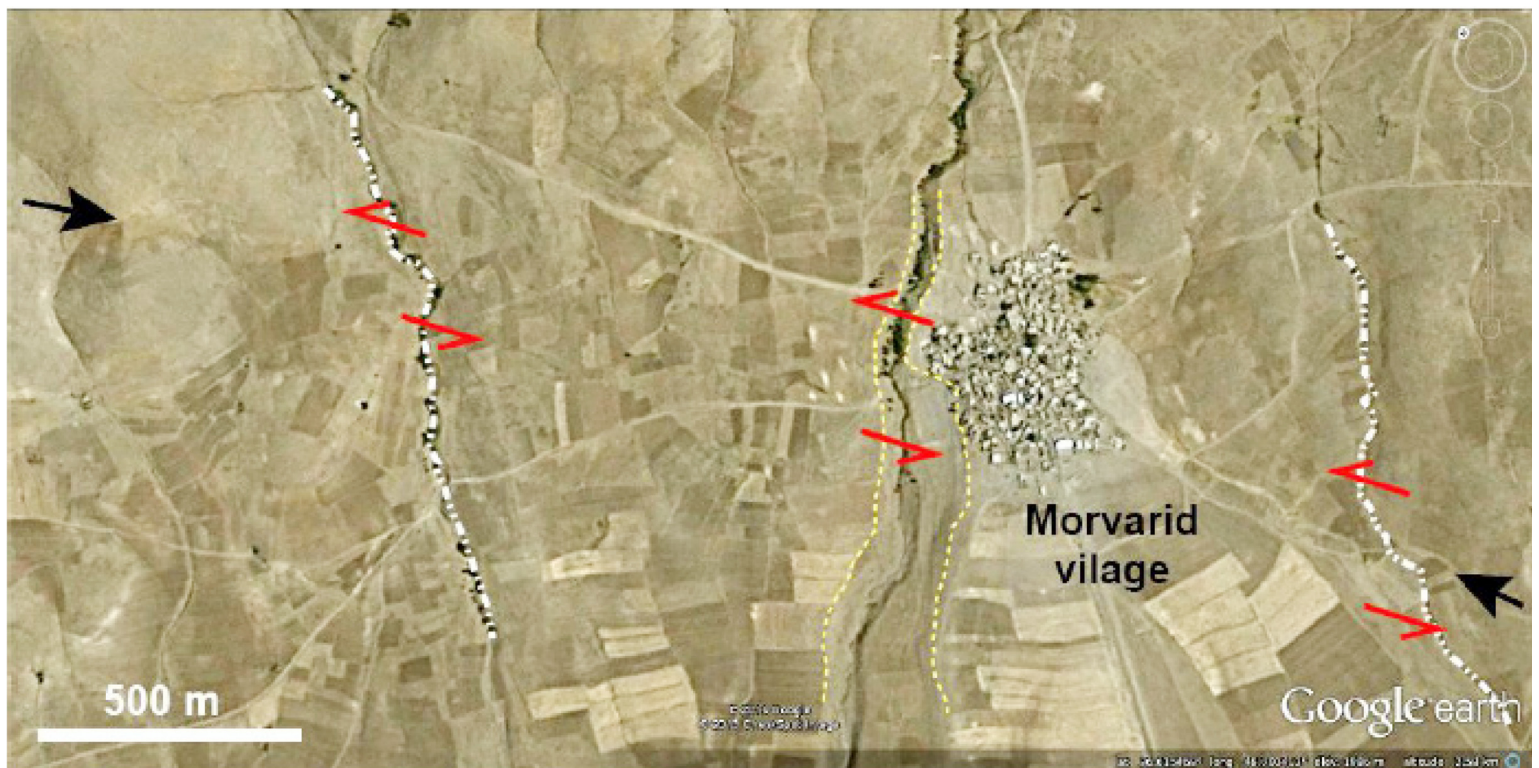

Figure 5. Sinistral cross-cut drainages and Quaternary features by Morvarid fault (Google Earth, 2015).

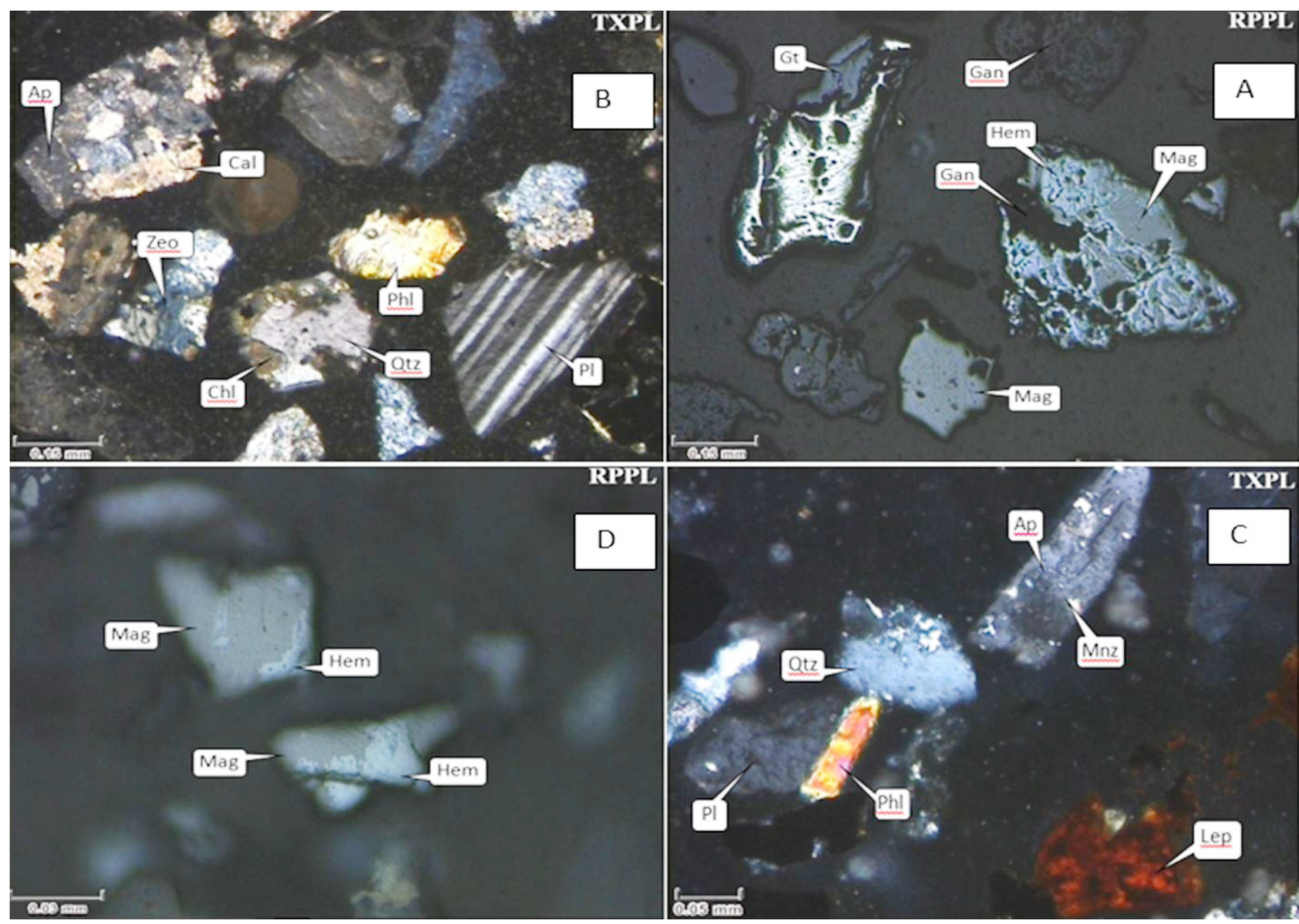

Figure 6. Petrography of samples at different scales (SEM-BSE images): (A) Magnetite and hematite are involved by gang, pyrite is replaced by goethite (+150-300) microns; (B) photo micrograph of plagioclase, quartz, apatite, calcite, zeolite, phlogopite and chlorite (+150-300) microns; (c) gang minerals specially quartz, plagioclase, phlogopite, lepidocrocite, as well as monazite involvement in apatite (+75-150) microns; (D) Existence of free magnetite and hematite in Sample (-75) microns. Mag = magnetite; Hem = hematite; Cal = calcite; Qtz=quartz; Phl=phologopite; $P$ I = plagioclase; $A p=$ apetite; Zeo = zeolite; $M o n=$ monazite; Cal = calcite; Lep = lepidocrocite; Gan = gang.

and gravity field can be calculated from the horizontal derivative by the Hilbert transform, denoted as H. It is subjected to a fast and accurate method of computing the vertical derivative from a given magnetic or gravity profile.

$$
\partial M / \partial z=H[\partial M / \partial x]
$$

where $\mathrm{M}$ is the magnetic or gravity anomaly data. Furthermore, these two quantities can be combined into a two-dimensional quantity known 
as the Analytic Signal (AS):

$$
A S(x, z)=\partial M / \partial x+i \partial M / \partial z
$$

where $i$ denotes imaginary number. The amplitude of the analytic signal is defined as:

$$
|A S(z)|=\sqrt{(\partial M / \partial x)^{2}+(\partial M / \partial z)^{2}}
$$

The amplitude of the analytic signal is a symmetric bell-shaped function (Hsu et al., 1998; Ansari and Alamdar, 2010). By examining its profile across a magnetic source, the analytic signal can be used to show the edges of the causative body. Similarly, for the 3-D case, the analytic signal is given by Blakely (1996):

$$
A S(x, y)=(\partial M / \partial x)+(\partial M / \partial y)+i(\partial M / \partial z)
$$

where its amplitude is defined as

$$
|A S(x, y)|=\sqrt{(\partial M / \partial x)^{2}+(\partial M / \partial y)^{2}+(\partial M / \partial z)^{2}}
$$

As aforementioned, the maximum value of the analytic signal determines the edges of a magnetic or gravity body. However, the use of analytic signal in the 3-D case seems insufficient to detect geologic boundaries for the sake of the interference effects from adjacent causative bodies. Under these conditions, the detected edges from the bodies are not detachable. Since the existing interference condition in many cases is not negligible, the enhancement of its resolution or using other replacement techniques becomes important.

Subsequently, the results of that are used to build a structural model to help understand the subsurface structure of the study area. Hence, the structure of basement faults is extracted from airborne magnegometric map (Fig. 7). The rose diagram is generated based on the extracted basement faults and the trend of faults is NW-SE, as presented in Fig. $8 \mathrm{~b}$. The main trend of the basement faults is correlated with major trends of other types of faults especially active and Quaternary faults as shown in Fig. 4.

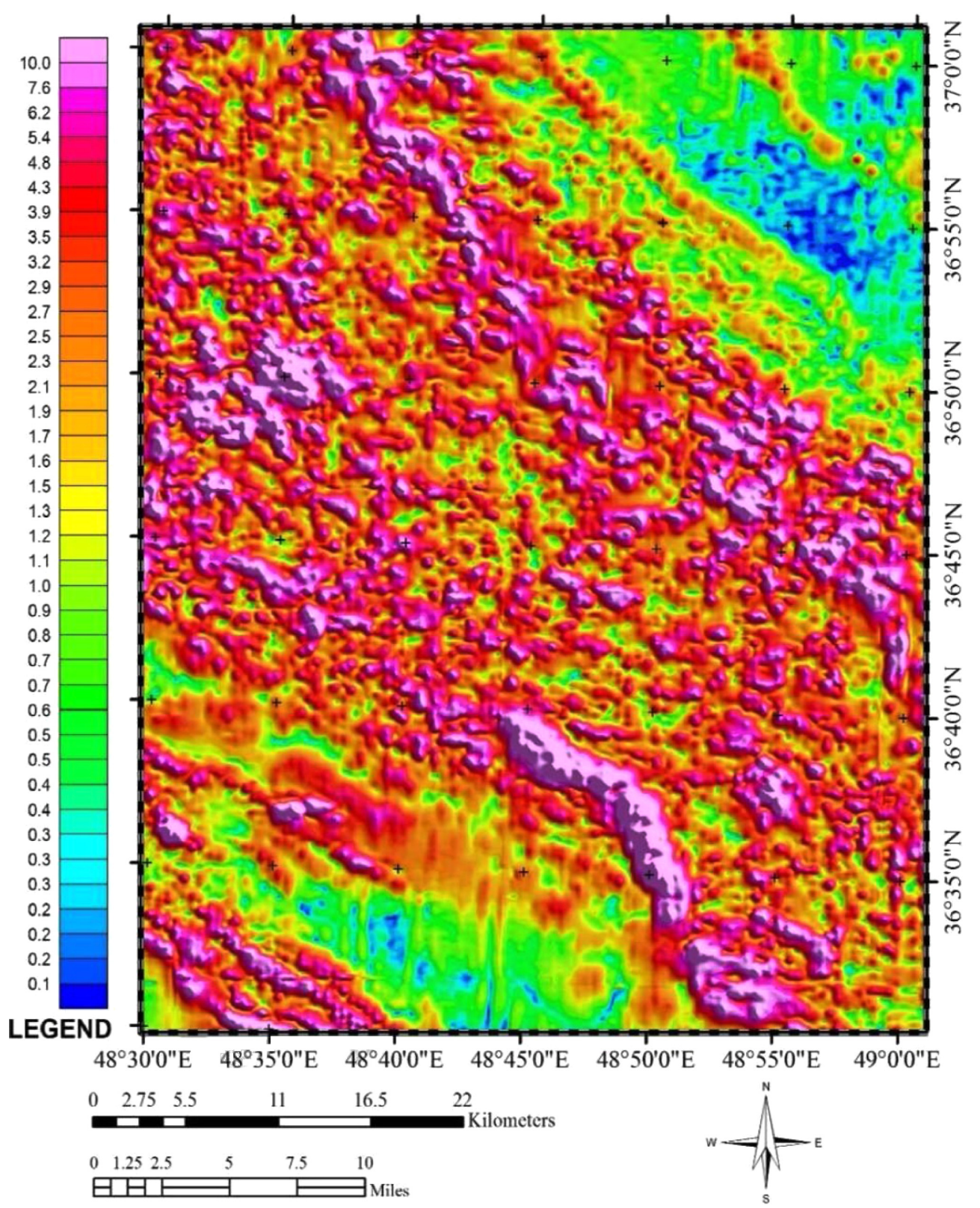

Figure 7. The magnetic maps based on airborne magnetic data with the "Analytic signal" filter in 1:100,000 Tarom area. 

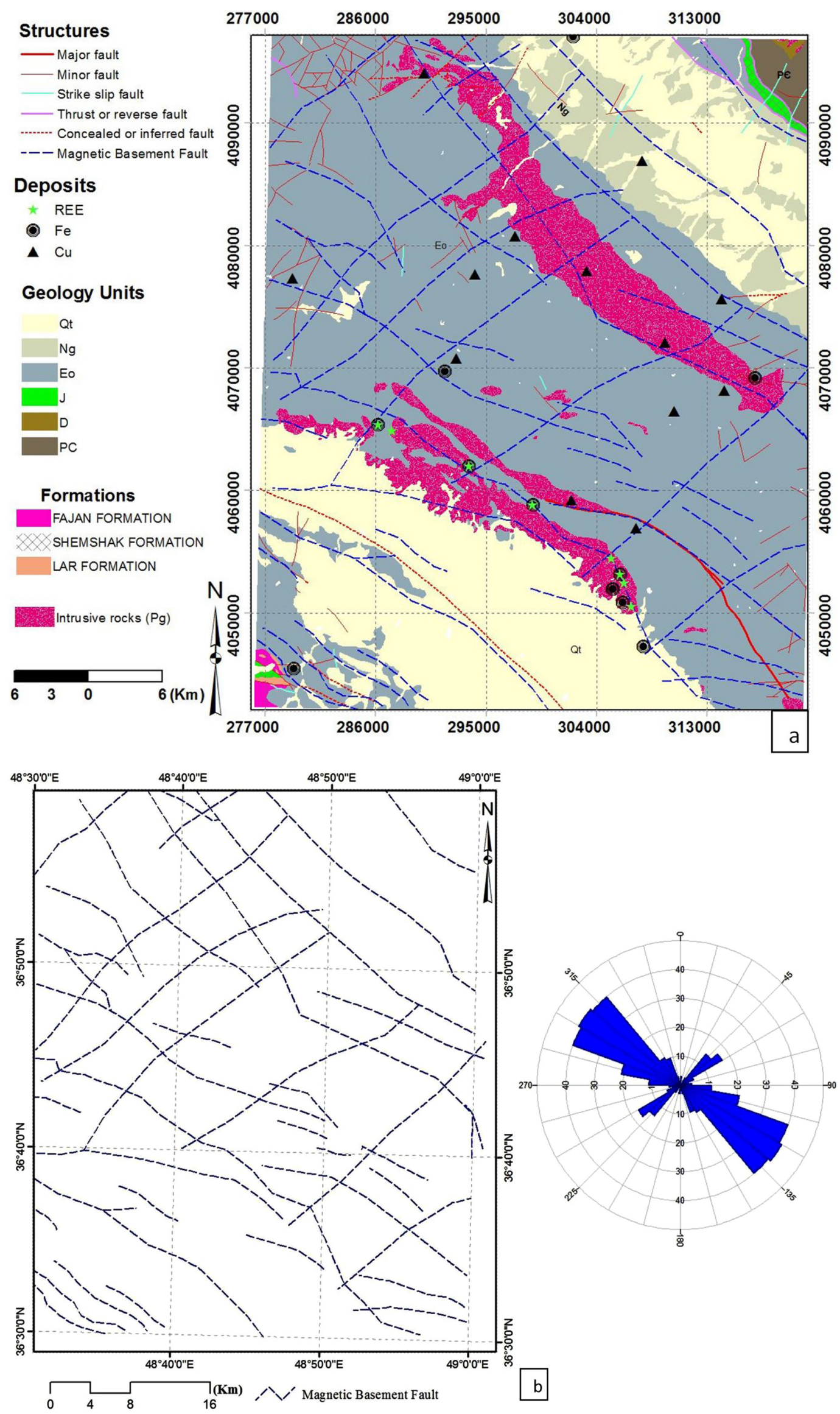

Figure 8. a) The basement faults map which are detected from Analytic signal magnetic data (Fig. 6); b) magnetic basement faults map and its rose diagram. 


\section{C-DMF Fractal Model}

The methods based on fractal geometry in geological sciences are applied to analyze the intricate forms of geological features, especially in the branch of structural geology. Fractal analysis is also useful to characterize and separate the geochemical and mineralized populations, particularly in economic geology, mineral exploration and geophysics (Cheng, 1999; Carranza, 2008; Afzal et al., 2014). The principles of these methods are the reverse relationship between occupied geometrical spaces (perimeter, area, volume or distance to a geological event) and the regionalized variables (e.g., elemental concentration; Khalajmasoumi et al., 2016; Afzal et al., 2017). This model has the following equation (based on Nouri et al., 2013):

$$
\operatorname{DBF}(\geq \rho) \infty \mathrm{F}^{-\mathrm{D}}
$$

As observed in the equation, the basement faults extracted from magnetic map. $\rho$ and $\mathrm{D}$ show elemental concentration and fractal dimension in equation 1 . In this research, it is used as a Concentration-Distance to Magnetic Faults (C-DMF) fractal method.

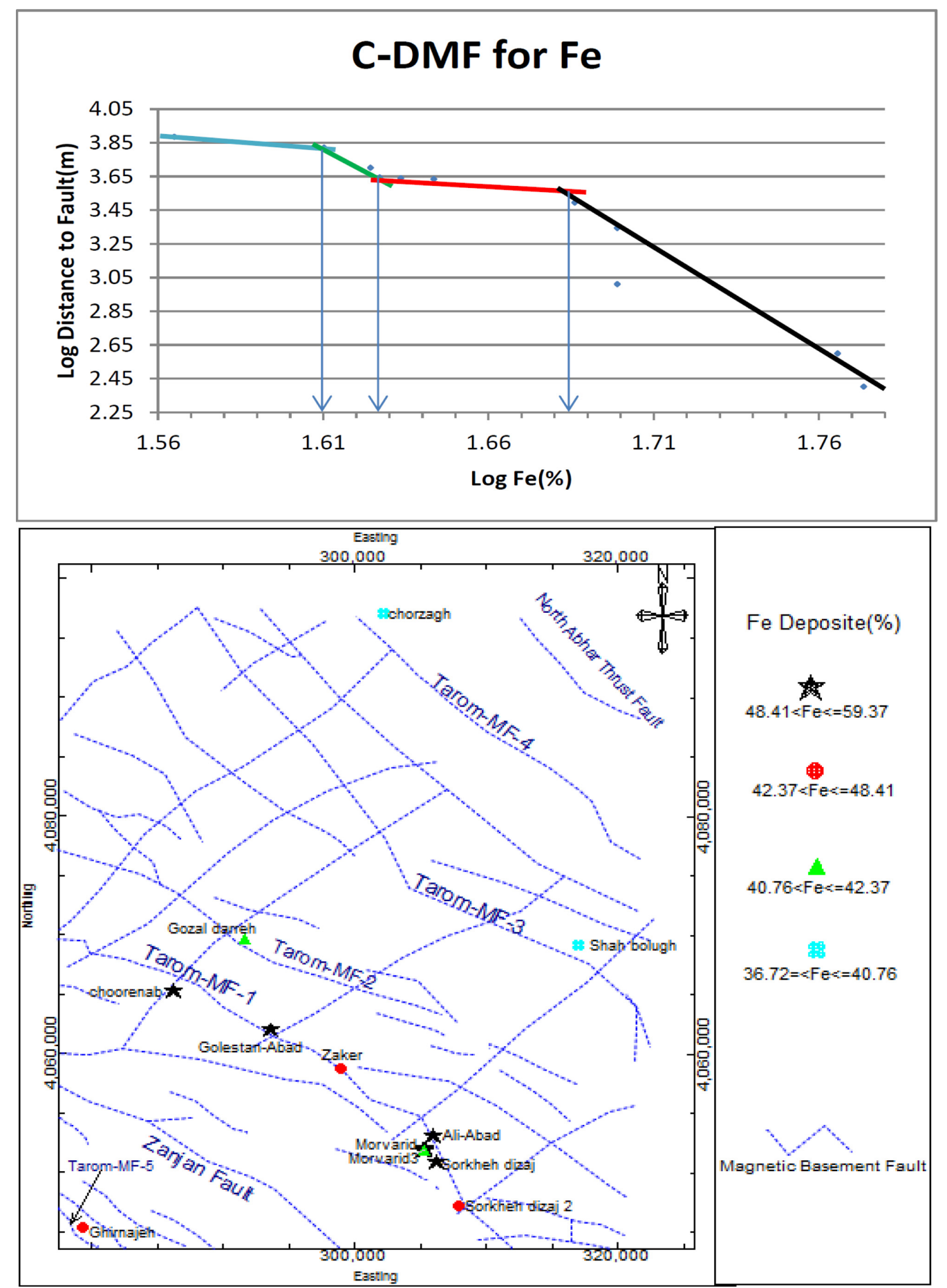

Figure 9. The C-DMF fractal modeling for relationship between Fe mines/deposits and the magnetic basement faults. 


\section{Results and Discussion}

As a result of the $\mathrm{C}$-DMF model, $\mathrm{Fe}, \mathrm{Cu}$ and REEs mineralization were classified according to their distance to faults. This modeling includes the log-log plots as display in Figs. 9, 10 and 11. Tables 1-3 demonstrates the components of this model. The faults that play an important role in the $\mathrm{Fe}, \mathrm{Cu}$ and REEs mineralization includes the
Tarom-MF1, Tarom-MF2, Tarom-MF3, Tarom-MF4, Tarom-MF5, and Tarom-MF6. Based on Fig. 9, it can be seen that Fe concentrations in mine/deposits increase close to the faults. The $\mathrm{Fe}, \mathrm{Cu}$ and REEs concentrations were classified by the C-DMF models as depicted in Figs. 9, 10 and 11, and Tables 1-3. There are four populations for Fe and $\mathrm{Cu}$ and three populations for REEs. Main ore mineralization thresholds for $\mathrm{Fe}, \mathrm{Cu}$ and REEs are $48.41 \%, 3.8 \%$ and $946.71 \mathrm{ppm}$, respectively.

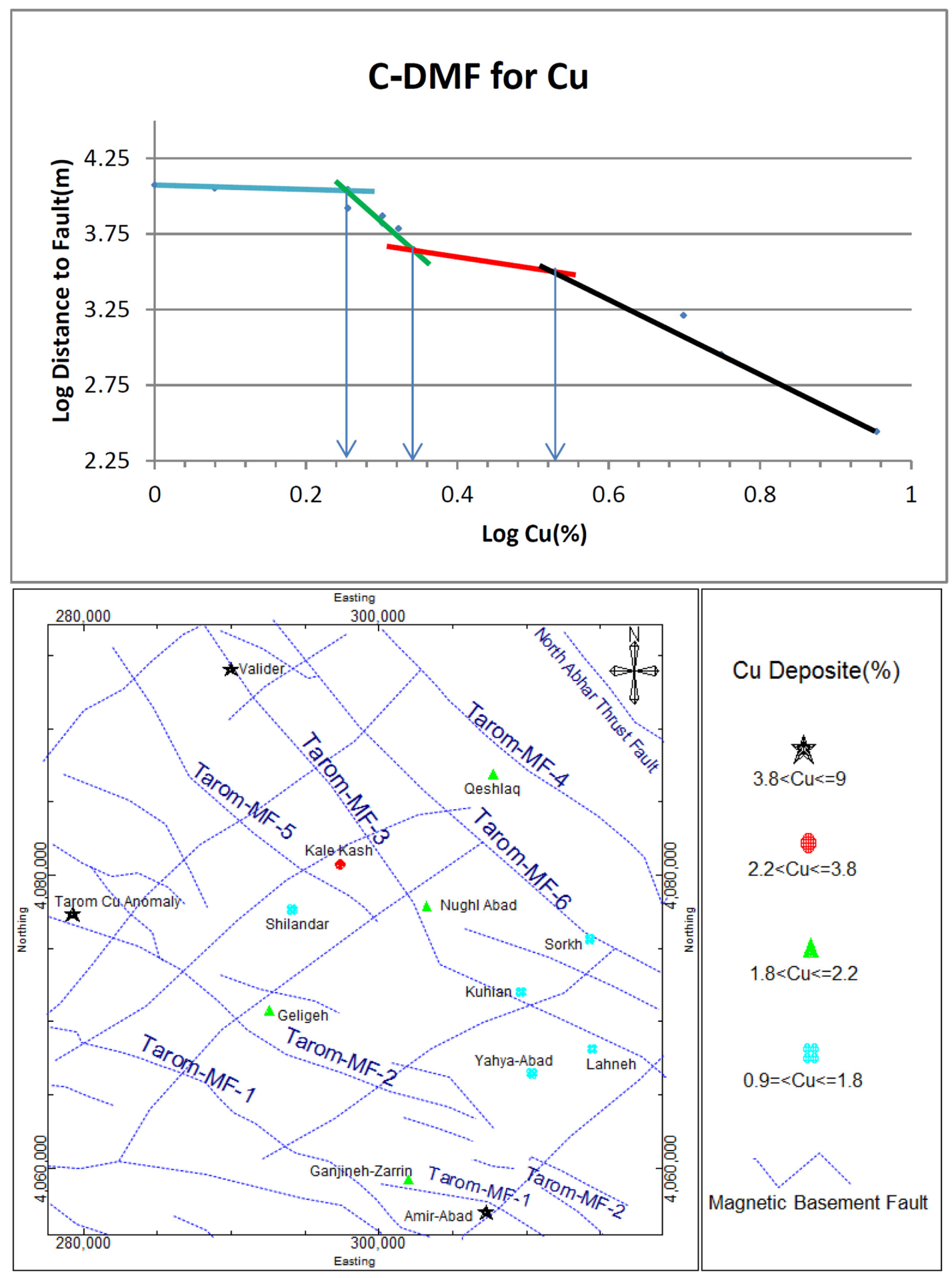

Figure 10. The C-DMF fractal modeling for the relationship between Cu mines/deposits and the magnetic basement faults. 


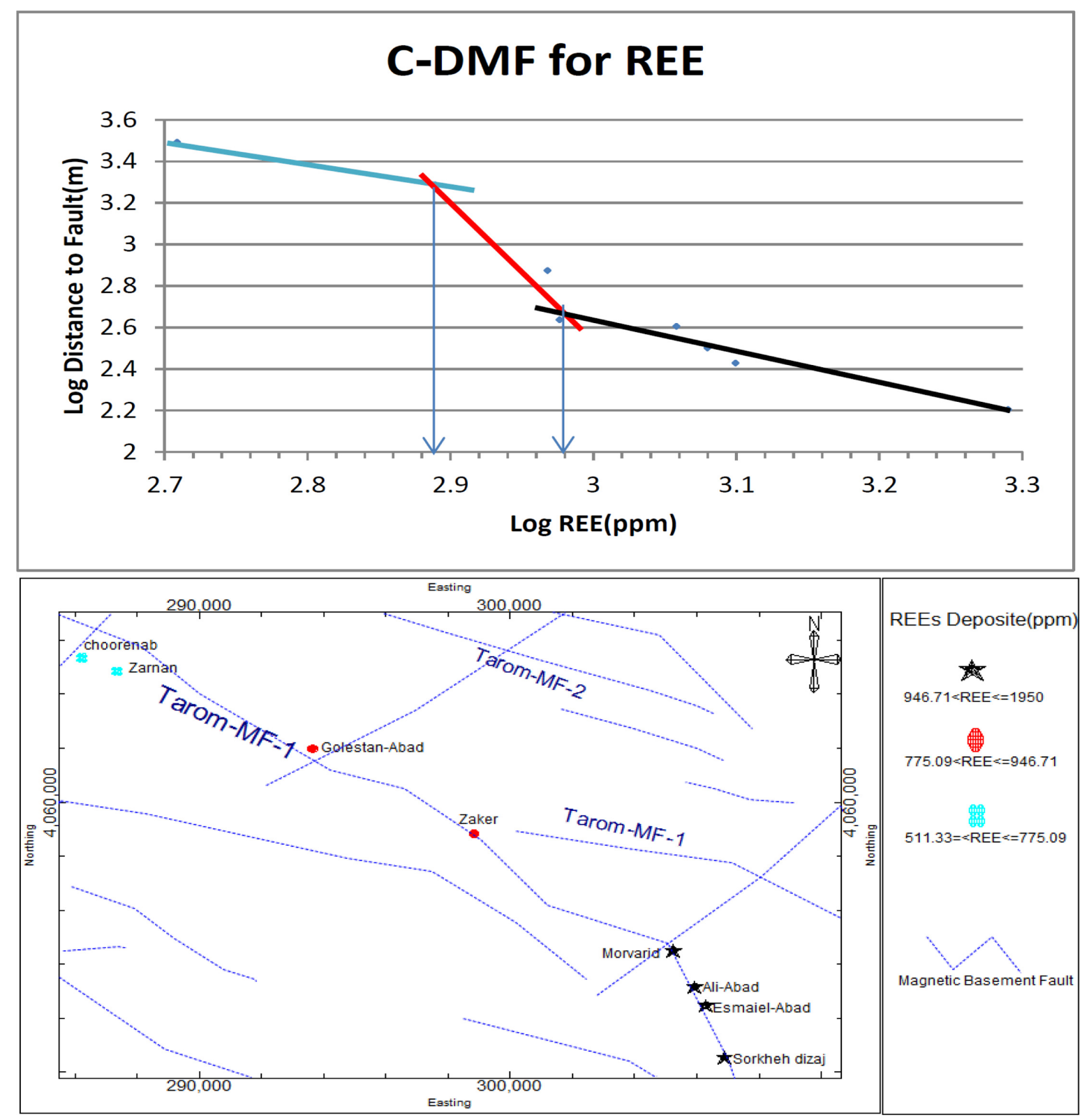

Figure 11. The C-DMF fractal modeling for relationship between REEs mines/deposits and the magnetic basement fault. This model contains of logarithmic fractal diagram and the symbol map with the color-scheme based on that.

Choorenab mine has Fe average equal to $50 \%$ (Table 1) which has the highest distance $(1181 \mathrm{~m})$ and Morvarid 3 mine with $\mathrm{Fe}$ mean $=42.4 \%$ which has the lowest distance ( $44 \mathrm{~m}$ ) to the TAROM-MF1 fault. The distance of Shah Bolugh mine with Fe an average of $34 \%$ to the TAROMMF3 fault is $1060 \mathrm{~m}$. The distance of Gozal Dareh (Fe mean=42.1\%) to the TAROM-MF4 fault is $624 \mathrm{~m}$. Chorzagh mine with an average of Fe equal to $40.8 \%$ has the longest distance $(1591 \mathrm{~m}$ ) and Ghinarjeh mine with $\mathrm{Fe} 44 \%$ ore average grade which has the shortest distance $(730 \mathrm{~m})$ to the TAROM-MF5 fault. The highest value of $\mathrm{Fe}(59.4 \%)$ is related to Golestan Abad mine (Table 1), whose distance to TAROMMF1 fault is $253 \mathrm{~m}$. Also, the lowest value of Fe (59.4\%) in Table 1 is related to Shah Bolugh mine whose distance to Tarom-MF3 fault is $1060 \mathrm{~m}$. Mechanisms of nearest Fault to all mines/deposits are reverse/thrust (Nouri et al., 2013).

With respective averages of 5\% and 2\%, Amir Abad and Ganjineh
Zarrin mines have the longest distance $(732 \mathrm{~m})$ and shortest distance $(521 \mathrm{~m})$ to the TAROM-MF1 fault, respectively (Table 2). In addition, Geligeh mine with $\mathrm{Cu}$ mean equal to $2.2 \%$ has the longest distance (1278 m; Table 2) to this fault. Furthermore, the Tarom Anomaly mine with $\mathrm{Cu} 5.6 \%$ has the shortest distance $(621 \mathrm{~m})$ to the TAROMMF2 fault. Yahya Abad and Valider mines have $\mathrm{Cu}$ mean equal to $0.9 \%$ and $9 \%$. respectively, and have the corresponding longest distance $(4131 \mathrm{~m})$ and shortest distance $(621 \mathrm{~m})$ to the TAROM-MF3 fault. The distance of Qeshlaq mine with $\mathrm{Cu} 2.1 \%$ to the TAROM-MF4 fault is $1690 \mathrm{~m}$. Shilandar mine with $\mathrm{Cu} 1.8 \%$ has the longest distance (2746 m) and Kale Kash mine with $\mathrm{Cu} 3.4 \%$ has shortest distance $(1523 \mathrm{~m})$ to the TAROM-MF5 fault. The distance of Sorkh mine with $\mathrm{Cu} 1.2 \%$ to the TAROM-MF6 fault is $224 \mathrm{~m}$.

The highest value of $\mathrm{Cu}(9 \%)$ in Table 2 is related to Valider mine, whose distance to TAROM-MF3 fault is $278 \mathrm{~m}$. Furthermore, the 
Table 1. Concentration-Distance to Magnetic Faults (C-DMF) model components for Fe

\begin{tabular}{|c|c|c|c|c|}
\hline Deposite/Mine Name & $\mathrm{Fe}(\%)$ & Distance to fault (m) & The nearest fault & Population in log-log plot \\
\hline Sorkheh Dizaj & 50 & 628 & Tarom-MF1 & Black \\
\hline Morvarid3 & 42.4 & 44 & Tarom-MF1 & Green \\
\hline Zaker & 43 & 55 & Tarom-MF1 & Red \\
\hline Choorenab & 50 & 1181 & Tarom-MF1 & Black \\
\hline Golestan Abad & 59.4 & 253 & Tarom-MF1 & Black \\
\hline Morvarid & 48.5 & 918 & Tarom-MF1 & Black \\
\hline Sorkheh Dizaj2 & 48.4 & 451 & Tarom-MF1 & Red \\
\hline Shah Bolugh & 34 & 1060 & Tarom-MF3 & Blue \\
\hline Gozal Dareh & 42.1 & 624 & Tarom-MF4 & Green \\
\hline Chorzagh & 40.8 & 1591 & Tarom-MF5 & Blue \\
\hline
\end{tabular}

Table 2. Concentration-Distance to Magnetic Faults (C-DMF) model components for Cu

\begin{tabular}{|c|c|c|c|c|c|}
\hline Deposite/Mine Name & $\mathrm{CU} \%$ & Distance to fault (m) & The nearest fault & Fractal population & References for each mines/deposites \\
\hline Amir Abad & 5 & 732 & Tarom-MF1 & Black & (Ganji, 2005) \\
\hline Ganjineh Zarrin & 2 & 521 & Tarom-MF1 & Green & Ganji, 2005) \\
\hline Tarom Anomaly & 5.6 & 621 & Tarom-MF2 & Black & (Nazarinia et al., 2011) \\
\hline Geligeh & 2.2 & 1278 & Tarom-MF2 & Green & (Nazarinia et al., 2011) \\
\hline Kuhian & 1 & 555 & Tarom-MF3 & Blue & (Nouri et al., 2013) \\
\hline Nughl Abad & 2 & 779 & Tarom-MF3 & Green & (Nouri et al., 2013) \\
\hline Valider & 9 & 278 & Tarom-MF3 & Black & (Ganji, 2005) \\
\hline Lahneh & 1.8 & 933 & Tarom-MF3 & Blue & (Ganji, 2005) \\
\hline Yahya Abad & 0.9 & 4131 & Tarom-MF3 & Blue & (Nazarinia et al., 2011) \\
\hline Qeshlaq & 2.1 & 1690 & Tarom-MF4 & Green & (Nazarinia et al., 2011) \\
\hline Kale Kash & 3.4 & 1523 & Tarom-MF5 & Red & (Nazarinia et al., 2011) \\
\hline Shilandar & 1.8 & 2746 & Tarom-MF5 & Blue & (Nouri et al., 2013) \\
\hline Sorkh & 1.2 & 224 & Tarom-MF6 & Blue & (Nouri et al., 2013) \\
\hline
\end{tabular}

Table 3. Concentration-Distance to Magnetic Faults (C-DMF) model components for REEs

\begin{tabular}{|c|c|c|c|c|}
\hline Deposite/Mine Name & "REEs ppm & Distance to fault (m) & fractal population & "Mine/Deposit References \\
\hline Ali Abad & 1257 & 108 & Black & (Korei et al., 2016) \\
\hline Zarnan & 511.3 & 1174 & Blue & (Korei et al., 2016) \\
\hline Choorenab & 775.1 & 1186 & Blue & (Korei et al., 2016) \\
\hline Golestan Abad & 928.7 & 315 & Red & (Korei et al., 2016) \\
\hline Zaker & 946.7 & 30 & Red & \\
\hline Esmaiel Abad & 1950 & 160 & Black & \\
\hline Sorkheh Dizaj & 1143 & 86 & Black & \\
\hline
\end{tabular}

lowest value of $\mathrm{Cu}(0.9 \%)$ in this table is related to Yahya Abad mine, with its distance to Tarom-MF3 fault as $4131 \mathrm{~m}$. The Choorenab mine with an average value of REES as $775.1 \mathrm{ppm}$ has the longest distance $(1186 \mathrm{~m})$ and Zaker with the value of REEs $946.7 \mathrm{ppm}$ has the shortest distance (30 m) to the TAROM-MF1 fault (Table 3).

The highest value of REEs (1950 ppm) in Table 3 is related to Esmaiel Abad mine, with its distance to TAROM-MF1 fault being $160 \mathrm{~m}$. Additionally, the lowest value of REEs (511.3 ppm) in this table is related to Zarnan mine, whose distance to Tarom-MF1 fault is $1174 \mathrm{~m}$.
Based on Figs. 9, 10 and 11 and Tables 1, 2 and 3, the following results can be observed:

1) Tarom-MF1 is the nearest fault to Sorkheh-Dizaj, Sorkheh dizaj2, Morvarid, Morvarid 3, Zaker, Choorenab, Golestan Abad and Ali Abad Fe deposits.

2) Tarom-MF3 is the nearest fault to Shah Bolugh Fe deposit.

3) Tarom-MF4 is the nearest fault to Gozal Dareh Fe deposit.

4) Tarom-MF5 is the nearest fault Chorzagh, Ghinarjeh Fe deposits.

According to Fig. 10 and Table 2, it can be found that Tarom-MF1 
is the nearest fault to Sorkheh Dizaj, Zaker, Choorenab, Golestan Abad, Morvarid, Esmaiel Abad, Zarnan and Ali Abad $\mathrm{Cu}$ deposits. Fig. 11 and Table 3 show Tarom-MF1 as the nearest fault to SorkhehDizaj, Zaker, Choorenab, Golestan Abad, Morvarid, Esmaiel Abad, Zarnan and Ali Abad REEs deposits.

At this point all the distances between the deposits and the nearest fault are in Tables 1, 2 and 3. Similarly, based on C-DMF model (Fig. 9) all the distances of the high grade mineralization values to the nearest magnetic faults are less than $918 \mathrm{~m}$ and in the Table 1, the last population has high-grades mineralization values with grades of $48.41 \%$ $\leq \mathrm{Fe} \leq 59.37 \%$. Furthermore, as seen in Fig. 10 and Table 2, the last population with the grades between 5 and $9 \%$ for $\mathrm{Cu}$, and related distances are less than $1523 \mathrm{~m}$. Nevertheless, observing Fig. 11 and Table 3, we can find that the distances (to the related faults) less than 86 meter are related to REEs concentration between 946.71 and $1950 \mathrm{ppm}$ as the last population. Consequently, the main REEs mineralization are located near a magnetic basement fault at SE part of the study map, as depicted in Fig. 11. In addition, the main iron ores are situated in the central and southern parts of the map Fig. 9. Major $\mathrm{Cu}$ deposits are located in the western, SE and NW parts of this map, as shown in Fig. 10.

\section{Conclusion}

Based on the results of this study, there is a direct relationship between increasing Fe concentration of study area deposits with extending the distance to the nearest fault, using C-DMF fractal modeling. This methodology can be used for an appropriate exploration in the other similar regions. According to the amount of $\mathrm{Fe}, \mathrm{Cu}$ and REES grades of mines, high $\mathrm{Fe}$ and REES concentrations are in the south of Tarom area but the concentration of $\mathrm{Cu}$ is reduced from N-NW to S-SW of the study area. In this way, the high grades of $\mathrm{Cu}$ are located in the $\mathrm{NW}, \mathrm{W}$ and centre of Tarom geology map, with the high $\mathrm{Cu}$ concentration and the grades 3.8-9\% (except Amir Abad high-grade Cu deposit which is in the south). Likewise, the iron, copper and REEs ore deposits of study area were classified well by means of the mentioned fractal relations. Regarding the last population in C-DMF diagrams with the grades between 48.41 and $59.37 \%$ thresholds in Fe, 5 and $9 \%$ thresholds in $\mathrm{Cu}$ and also 946.71 and $1950 \mathrm{ppm}$ thresholds in REEs, the distances are progressively smaller than 918,1523 and 86 meters to the first generation of mantic fault (NW-SE).

Hence, the basement faults are visible on the magnetic maps according to the results of logarithmic diagrams. They have the minimum distance to high concentrations of $\mathrm{Fe}$, and REEs deposits. In other words, the basement or main faults are the factor of structural controller of these deposits/mines and $\mathrm{Cu}$ mineralization. It was revealed by the proximity of reverse basement faults with the mine/deposits and their impact on mineralization in Late Eocene units. Occurring in the extensional fractures, mineralization was formed because of the intrusion in Late Eocene. Consequently, the continental crust became fragile due to the normal fault. Then, the lava and fluids ascended and deposited in the middle of sediments and surface by the fragile crust and extensional fractures where intrusions have occurred. These normal faults changed into the reverse faults next to the $\mathrm{Fe}, \mathrm{Cu}$ and REEs mineralization after the closure of these basement faults in the next periods. Accordingly, the $\mathrm{Fe}, \mathrm{Cu}$ and REES mineralization appeared in the greatest depth and under the wrinkled sediments with faulting. It can be inferred that mineralization has been influenced by the Eocene and Late Eocene.

\section{Acknowledgments}

Authors would like to appreciate the Iranian Mining Industries Development and Renovation Organization (IMIDRO) and Research and Technology deputy of Islamic Azad University/South Tehran Branch for its financial support in this research project. The reference code of this research project contract is B.16.896.

\section{References}

Adib, A., Mirzaei Ilani, Sh., Shoaei, G.h., and Afzal, P., 2017, Determination of a conceptual model for the structural features and $\mathrm{Pb}-\mathrm{Zn}$ mineralization in the north of Behabad Fault Zone, Central Iran. Iranian Journal of Earth Sciences, v. 9, pp. 168-183.

Afzal, P., Alhoseini, S.H., Tokhmechi, B., Kaveh Ahangaran, D., Yasrebi, A.B., Madani, N., and Wetherelt, A., 2014, Outlining of high quality coking coal by concentration-volume fractal model and turning bands simulation in East-Parvadeh coal deposit, Central Iran. International Journal of Coal Geology, v. 127, pp. 88-99.

Afzal, P., Madani, N., Shahbeik, S., and Yasrebi, A.B., 2015, Multi-Gaussian kriging: a practice to enhance delineation of mineralized zones by concentration-volume fractal model in Dardevey iron ore deposit, SE Iran. Journal of Geochemistry Exploration, v. 158, pp. 10-21.

Afzal, P., Ahmadi, K., and Rahbar, K., 2017, Application of fractal-wavelet analysis for separation of geochemical anomalies. Journal of African Earth Sciences, v. 128, pp. 27-36.

Agard, P., Omrani, J., and Jolivet, L., 2005, Convergence history across Zagros (Iran): Constraints from collisional and earlier deformation. International Journal of Earth Sciences, v. 94, pp. 401-419

Agterberg, F.P., 2012, Multifractal and geostatistics. Journal of Geochemistry Exploration, v. 122, pp. 113-122.

Ahmadfaraj, M., Mirmohammadi, M., Afzal, P., Yasrebi, A.B., and Carranza, E.J., 2019, Fractal modeling and fry analysis of the relationship between structures and $\mathrm{Cu}$ mineralization in Saveh region, Central Iran. Ore Geology Reviews, v. 107, pp. 172-187.

Allen, M.B., Ghassemi, M.R., Shahrabi, M., and Qorashi, M., 2003, Accommodation of late Cenozoic oblique shortening in the Alborz range, Northern Iran. Journal of Structural Geology, v. 25, pp. 659-672.

Ansari, A.H., and Alamdar, K., 2010, An improved method for geological boundary detection of potential field anomalies. Journal of Mining and Environment, v. 2, pp. 37-44.

Azizi, H., Tarverdi, M.A., and Akbar pour, A., 2010, Extraction of hydrothermal alterations from ASTER SWIR data from east Zanjan, northern Iran. Advances in Space Research, v. 46, pp. 99-109.

Blakely, R.J., 1996, Potential theory in gravity and magnetic application. Cambridge University Press, Cambridge, UK, 441 p.

Berberian, M., and King, G., 1981, Towards a paleogeography and tectonic evolution of Iran. Canadian Journal of Earth Sciences, v. 18, pp. 210-265.

Berberian, M., 1983, Structural evolution of the Iranian Plateau; Contribution to the seismotectonics of Iran, Part IV: Continental deformation in the Iranian Plateau. Geological Survey of Iran, Report 52, pp. 19-68.

Carranza, E.J.M., 2008, Geochemical anomaly and mineral prospectively mapping in GIS. Handbook of Exploration and Environmental Geochemistry, Elsevier, Amsterdam, v. 11, pp. 368.

Cheng, Q., Agterberg, F.P., and Ballantyne, S.B., 1994, The separation of geochemical anomalies from background by fractal methods. Journal of Geochemical. Exploration, v. 51, pp. 109-130.

Cheng, Q., 1999, Spatial and scaling modeling for geochemical anomaly 
separation. Journal of Geochemical Exploration, v. 65, pp. 175-194.

Daneshvar Saein, L., Rasa, I., Rashidnejad Omran, N., Moarefvand, P., and Afzal, P., 2012, Application of concentration volume fractal method in induced polarization and resistivity data interpretation for $\mathrm{Cu}-\mathrm{Mo}$ porphyry deposits exploration, case study: Nowchun $\mathrm{Cu}-\mathrm{Mo}$ deposit, SE Iran. Nonlinear Processes in Geophysics, v. 19, pp. 431-438.

Davoudzadeh, M., and Schmidt, K., 1984, A review of the Mesozoic paleogeography and paleotectonic evolution of Iran, Neues Jahrbuch Fur Geologie und Paläontologie, Abhandlungen, 168, pp. 182-207.

Ganji, A., 2005, Evaluation of mineral hydrothermal alteration central Tarom mountains, NW Iran. Iranian Journal of Crystallography and Mineralogy, v. 13, pp. 121-133.

Guest, B., Axen, G.J., Lam, P.S., and Hassanzadeh, J., 2006, Late Cenozoic shortening in the west-central Alborz mountains, northern Iran, by combined conjugate strike-slip and thin-skinned deformation. Geosphere, v. 2, pp. 35-52.

Hassanpour, S., and Afzal, P., 2013, Application of concentration-number (C-N) multifractal modeling for geochemical anomaly separation in Haft Cheshmeh porphyry system, NW Iran, Arabian. Journal of Geosciences, v. 6, pp. 957-970.

Hassanzadeh, J., and Wernicke, BP., 2016, The Neotethyan Sanandaj-Sirjan zone of Iran as an archetype for passive margin-arc transitions. Tectonics, v. 35, 586-621.

Hsu, S.K., Coppense, D., and Shyu, C.T., 1998, High resolution detection of geologic boundaries from potential field anomalies: An enhanced analytic signal technique. Geophysics, v. 61, pp. 1947-1957.

Karami, K., and Afzal, P., 2015, Application of multifractal modeling for separation of sulfidic mineralized zones based on induced polarization and resistivity data in the Ghare Tappeh $\mathrm{Cu}$ deposit, NW Iran. Iranian Journal of Earth Sciences, v. 7, pp. 134-141.

Khalajmasoumi, M., Sadeghi, B., Carranza, E.J.M., and Sadeghi, M., 2016, Geochemical anomaly recognition of rare earth elements using multi-fractal modeling correlated with geological features, Central Iran. Journal of Geochemical Exploration, v. 181, pp. 1-344.

Korei, M.T., Gharib, F., and Vaesa, S., 2016, Rare earth element (REEs) exploration in Iran, Investigating the REEs' potential in by-products of mines, Applied Research Center of the Geological Survey and mineral exploration of Iran, 114 p. (in Persian)

Kouhestani, H., Mokhtari, M.A.A., Qin, K., and Zhao, J., 2019, Fluid inclusion and stable isotope constraints on ore genesis of the Zajkan epithermal base metal deposit, Tarom-Hashtjin metallogenic belt, NW Iran. Ore Geology Reviews, v. 109, pp. 564-584.

Li, C., Ma, T., and Shi, J., 2003, Application of a fractal method relating concentrations and distances for separation of geochemical anomalies from background. Journal of Geochemical Exploration, v. 77, pp. 167-175.

Mandelbrot, B.B., 1983, The fractal geometry of nature. Freeman, San Fransisco, $468 \mathrm{p}$.

Meng, X., and Zhao, P., 1991, Fractal method for statistical analysis of geological data. Chinese Journal of Geosciences, v. 2, pp. 207-211.

Moinvaziri, H., 1985, Volcanisme tertiaire et quaternaire en Iran, These d'Etat, Université Paris-Sud, Orsay.

Mokhtari, M.A.A., Sadeghi, M., and Nabatian, Gh., 2018, Geochemistry and potential resource of rare earth element in the IOA deposits of Tarom area, NW Iran. Journal of Ore Geology Reviews, v. 92, pp. 529-541.

Mustansar, N., Jean-Pierre, B., Nasir, A., Muhammed, N., and Perveiz, K., 2016, U-Pb zircon systematics of the Mansehra Granitic Complex: implications on the early Paleozoic orogenesis in NW Himalaya of Pakistan. Geosciences Journal, v. 20, pp. 427-447.

Nabatian, Gh., Ghaderi, M., 2014, Mineralogy and geochemistry of rare earth elements in iron oxide-apatite deposits of the Zanjan region. Scientific Quarterly Journal of Geosciences, Geological Survey and Mineral Exploration of Iran, v. 24, pp. 157-170 (in Persian with English abstract).

Nabatian, Gh., Ghaderi, M., Neubauer, F., Honarmand, M., Liu, X., Dong, Y., Jiang, S-H., von Quadt, A., and Bernroider, M., 2014a, Petrogenesis of
Tarom high-potassic granitoids in the Alborz-Azarbaijan belt, Iran: Geochemical, U-Pb zircon and $\mathrm{Sr}-\mathrm{Nd}-\mathrm{Pb}$ isotopic constraints, Lithos, v. 184-187, pp. 324-345.

Nabatian, Gh., Ghaderi, M., Neubauer, F., Bernroider, M., Prokofiev, V., and Honarmand, M., 2014b, Geology, alteration, age, and origin of iron oxide-apatite deposits in Upper Eocene quartz monzonite, Zanjan district, NW Iran. Mineralium Deposita, v. 49, pp. 217-234.

Nabatian, Gh., Rastad, E., Neubauer, F., Honarmand, M., and Ghaderi, M., 2015, Iron and Fe-Mn mineralisation in Iran: implications for Tethyan metallogeny. Australian Journal of Earth Science, v. 62, pp. 211-241.

Nabatian, Gh., Li, X.H., Honarmand, M., and Melgarejo, J.C., 2017, Geology, mineralogy and evolution of iron skarn deposits in the Zanjan district, NW Iran: Constraints from U-Pb dating, Hf and $\mathrm{O}$ isotope analyses of zircons and stable isotope geochemistry. Ore Geology Reviews, v. 84, pp. 42-66.

Nabighian, M.N., 1972, The analytic signal of two dimensional magnetic bodies with polygonal cross section: Its properties and use for automated anomaly interpretation. Geophysics, v. 37, pp. 507-517.

Nabilou, M., Arian, M., Afzal, P., Adib, A., and Kazemi Mehrnia, A., 2018, Determination of relationship between basement faults and alteration zones in Bafq Esfordi region, Central Iran. Episodes, v. 41, pp. 143-159.

Nazarpour, A., 2018, Application of C-A fractal model and exploratory data analysis(EDA) to delineate geochemical anomalies in the Takab,1: 25,000 geochemical sheet, NW Iran. Iranian Journal of Earth Sciences, v. 10, pp. 173-180.

Nouri, R., Jafari. M.R., Arian, M., Feizi, F., and Afzal, P., 2013, Correlation between $\mathrm{Cu}$ mineralization and major faults using multifractal modelling in the Tarom Area (NW Iran). Geologica Carpathica, v. 64, pp. 409-416.

Pirajno, F., 2009, Hydrothermal mineral systems. Springer, Berlin, 1250p.

Safari, H., Faraji, Z., and Majidian, S., 2016, Identifying and evaluating enterprise architecture risks using FMEA and fuzzy victor. Journal of Intelligent Manufacturing, v. 27, pp. 475-486.

Sengor, A.M.C., 1984, The cimmeride orogenic system and the tectonics of Eurasia. Geological Society of America Special Paper, v. 195, pp. 1-82.

Solaymani Azad, S., Dominguez, S., Philip, H., Hessami, K., Forutan, M.R., Shahpasan Zadeh, M., and Ritz J. F., 2011, The Zanjan fault system: morphological and tectonic evidences of a new active fault network in the NW of Iran. Tectonophysics, v. 506, pp. 73-85.

Stockli, D.F., Hassanzadeh, J., Stockli, L.D., Axen, G., Walker, J.D., and Dewane, T.J., 2004, Structural and geochronological evidence for Oligo-Miocene intra-arc low angle detachment faulting in the TakabZanjan area, NW Iran. Abstract, Programs Geological Society of America, v. 36, pp. 319.

Tahmasbi, Z., Kiani, M., and Khalaji, A.A., 2016, Petrology and geochemistry of diabasic dikes and andesitic-basaltic lavas in Noor Abad Harsin Ophiolite, SE of Kermanshah, Iran. Journal of Earth Science, v. 27, pp. 935-944.

Tatar, M., and Hatzfeld, D., 2009, Microseismic evidence of slip partitioning for the Rudbar-Tarom earthquake (Ms 7.7) of 1990 June 20 in NW Iran. Geophysical Journal International, v. 176, pp. 529-541.

Turcotte, D.L., 1986, A fractal approach to the relationship between Ore grade and tonnage. Economic Geology, v. 18, pp. 1525-1532.

Vernant, P.h., Nilfroushan, F., Hatzfeld, D., Abbassi, M.R., Vigny, C., Masson, F., Nanakali, H., Martinod, J., Ashtiani, A., Bayer, R., Tavakoli, F., and Chery, J., 2004, Contemporary crustal deformation and plate kinematics in Middle East constrained by GPS measurements in Iran and northern Oman. Geophysical Journal International, v.157, pp. 381-398.

Wan, B., Deng, C., Najafi, A., Hezareh, M.R., Talebian, M., Dong, L., Chen, L. and Xiao, W., 2018, Fertilizing porphyry $\mathrm{Cu}$ deposits through deep crustal hot zone melting. Gondwana Research, V. 60, pp. 179-185.

Yasrebi, A.B., and Hezarkhani, A., 2019, Resources classification using fractal modelling in eastern Kahang $\mathrm{Cu}-\mathrm{Mo}$ porphyry deposit, Central Iran. Journal of Earth Sciences, v. 11, pp. 56-67. 


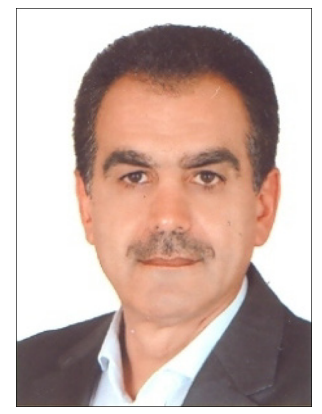

Ahmad Adib is Associate Prof. of structural geology and tectonics. He is an academic member of Petroleum and Mining department in Azad University, south Tehran branch, Iran. He has done many papers concerning Faulting, Seismology, Active tectonics, and relation between Structural Features and Mineralization.

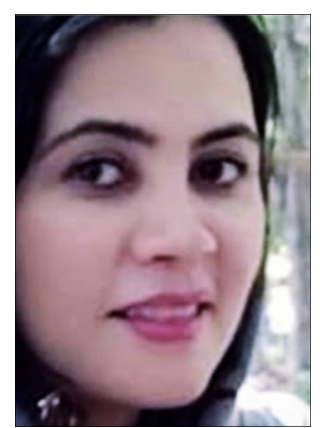

Masoumeh Nabilou is Ph.D in structural and economic geology. she does research in structural geology, Economic geology, Field and airborne geophysical exploration, Geostatistics and fractal modeling in earth sciences and she has some paper about above Expertise.

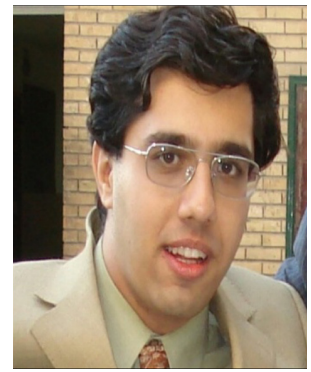

Peyman Afzal is Associate Prof. of Mining Engineering Department, Azad University, Iran. He does research in Economic Geology, Geochemistry, Geostatistics and fractal modeling in earth sciences. He is member of editorial board for "Iranian journal of Earth Sciences" and "Bulletin of the Mineral Research and Exploration". 